\title{
Negotiating Sacred Grounds? Resolving Islamist Armed Conflicts
}

\author{
Mimmi Söderberg Kovacs ${ }^{1}$ \\ Folke Bernadotte Academy, P.O. Box 270 68, SE 10251 Stockholm, Sweden \\ mimmi.soderbergkovacs@fba.se
}

Received 14 May 2020; accepted 19 June 2020

\begin{abstract}
Under what conditions can Islamist armed conflicts be resolved through peace negotiations? Armed conflicts involving Islamist groups have emerged as one of the most pressing challenges on the global agenda for peace and security. But the track record of conflict resolution in these settings is not encouraging. While armed conflicts have generally decreased in the post-Cold War period, as many prolonged civil wars were resolved through negotiated settlements, this has not been true to the same extent for this sub-category of conflicts. Yet, we know surprisingly little about why this is the case. The purpose of this thematic issue is to address this gap. Each contributor tackles a different angle of the overarching research problem.
\end{abstract}

\section{Keywords}

Islamist armed conflicts - peace negotiations - armed actors - religion transnationalism - ripeness

1 Mimmi Söderberg Kovacs is Head of Research at the Folke Bernadotte Academy and affiliated senior researcher with the Department of Peace and Conflict Research at Uppsala University in Sweden where she is a core member of the international research project 'Resolving Jihadist Conflicts? Religion, Civil War and Prospects for Peace'. She conducts research on rebel-to-party transformations, non-state actors in civil wars, conflict resolution, post-conflict democratization, and electoral violence. 
Under what conditions can Islamist armed conflicts be resolved through peace negotiations? ${ }^{2}$ On 29 February 2020, the United States and the Taliban in Afghanistan signed a long-awaited peace agreement after eighteen years of armed conflict and nine rounds of talks between the parties. The agreement is expected to lead to the withdrawal of American troops from the country, the beginning of intra-Afghani peace talks and the Taliban's distancing from Al-Qaeda (BBC 2020). On 10 February 2020, the President of Mali, Ibrahim Boubacar Keita, announced that he was exploring the option of political dialogue with the leadership of two armed Islamist groups in the north of the country in an effort to end the prolonged civil war that both the ongoing military counterinsurgency operation and the 2015 peace agreement had been unable to do. This was a radical break with the government's previous position, which up to that point had rejected all negotiations with the jihadists (RFI February 11, 2020).

These examples are encouraging. Armed conflicts involving Islamist groups have emerged as one of the most pressing challenges on the global agenda for peace and security. While such conflicts constituted a small minority of all armed conflicts at the end of the Cold War, the picture has now changed dramatically. In 2018, about half of all armed conflicts recorded by the Uppsala Conflict Data Program (UCDP) involved at least one armed group fighting for self-proclaimed Islamist political aspirations. ${ }^{3}$ Among these conflicts, we find some of the most violent wars of our time, such as those in Syria, Iraq, Afghanistan, Nigeria, Somalia, Pakistan, the Philippines, and Libya (Gleditsch \& Rudolfsen 2016). But so far, the track record of conflict resolution in these conflict settings is meager. While armed conflicts in the post-Cold War period have steadily decreased and many prolonged civil wars - from Cambodia, El Salvador and Mozambique to Northern Ireland, Liberia, and Nepal - have been resolved through negotiated settlements between the warring parties, this has not been true to the same extent for this sub-category of conflicts. This picture is consistent with the pattern and trend of religious conflicts more generally, where peace agreements tend to be more rare (Svensson \& Harding 2011; Svensson 2007, 2012). This suggests that there is something distinct about

2 Acknowledgments: I would like to thank the contributors to this Special Issue who provided valuable insights and constructive feedback on this Introduction. I gratefully acknowledge financial support from the Riksbankens Jubileumsfond.

3 This builds on data derived from the Uppsala Conflict Data Program (UCDP) and from the Religion and Armed Conflict (RELAC) data set (Svensson \& Nilsson 2018). For more information, please visit https://www.pcr.uu.se/research. 
these armed conflicts that make them less likely to be resolved through traditional conflict resolution methods.

Yet, we know surprisingly little about why this is the case. There is a glaring gap in both our scholarly understanding and in international practice circles concerning if, how, and to what extent, our existing theories, approaches and tools for negotiation are applicable or not to these armed conflicts. This opens a range of relevant questions: Are the warring parties in these conflicts fundamentally different than other conflict actors? What, if anything, sets these conflicts apart and why? What are the implications for negotiations? When are negotiations both a relevant and suitable option for conflict resolution in these conflicts? What can be negotiated, by whom, and when? What are some conceivable consequences of negotiating with Islamist armed groups?

The purpose of this thematic issue is to address this gap. Each of our contributors tackle a different angle of this overarching research problem. Desirée Nilsson and Isak Svensson use new disaggregated data to provide both a more informed and a more nuanced assessment of the correlation between Islamist armed conflicts and the likelihood of negotiations. Mona Kanwal Sheikh provides a detailed review of peace negotiations with the Pakistani Taliban for the purpose of understanding if the group's religious demands were the reason why these talks failed to bring the conflict to a close. Similarly, Mimmi Söderberg Kovacs looks at the many failed peace negotiations between the government of Nigeria and the armed group known as Boko Haram, and examines whether the group's religiously framed demands or its transnational organizational structure contributed to their downfall. Ioana Emy Matesan revisits the scholarly debate on ripeness and discusses when negotiations with Islamist armed actors should be pursued, based on an in-depth case analysis of al-Gama'a al-Islamiyya in Egypt. Anders Engvall and Isak Svensson depart from the discussion on ripeness to analyze peace negotiations in the Patani separatist conflict in Thailand.

To introduce these studies, I have identified three clusters of factors that need to be taken into consideration to better understand the conditions under which Islamist armed conflicts can be resolved through peace negotiations. These clusters are organized under three headings: negotiate with whom, when and about what? Based on the individual contributions to this issue, I summarize the main questions that shape the ongoing scholarly debate in each cluster, and the preliminary evidence of their relative explanatory power. In addition, I also highlight some novel factors identified in the articles, with the potential to contribute to new lines of theory development in this field of research. Lastly, some implications for both future research and policy and practice are discussed. 


\section{Reconsider Representation: Negotiate with Whom?}

The first cluster of factors considers questions related to the actors involved in these conflicts. The religious framing of the political demands of Islamist actors has resulted in a tendency by outside actors, not least policymakers, to refer to these groups as 'violent extremists,' a choice of terminology that indicates that they are both more ideologically radical and seemingly less rational than other armed actors. This, in turn, gives the impression that there is less room for compromise and bargaining, rendering political negotiation irrelevant or pointless. But the empirical findings from the case studies included in this issue do not support this argument. Instead, they show that even the most intransigent groups known for their religious devotion and ideologically rigid demands sometimes come to the negotiation table. As illustrated by the case studies of al-Gama'a al-Islamiyya in Egypt, Boko Haram in Nigeria and the Taliban movement in Pakistan, in spite of their ideological rhetoric, the demands of these groups at the negotiation table have been both limited and pragmatic, although not necessarily addressing the key conflict issues at stake. Interestingly, the most reluctant or obstinate party at the negotiation table in the cases studies included in this collection have been the governments fighting these non-state Islamist armed groups, who have often refused to meet even relatively moderate demands or reneged on previous commitments made at the negotiation table. Notably, in the few well-known cases of negotiated settlements with Islamist armed groups - such as the peace agreement between the Government of the Philippines and the Moro Islamic Liberation Front (MILF) in 2014 - key changes in both the attitude and behavior of the government have been suggested as critical factors that eventually bore fruit in the negotiations. ${ }^{4}$

Although none of the articles included in this collection find that religious devotion per se plays a key role in preventing Islamist armed groups from getting to the negotiation table, they all identify other aspects related to the structure and organization of these actors that is likely to negatively affect the prospect of peace talks. In particular, several of the articles point to the transnational nature of some of these organizations as a potentially important explanatory factor. Nilsson and Svensson look at the global picture of relationships between types of armed conflicts and the likelihood of negotiations. They find that while there is no discernible difference between conflicts fought over

4 Author interview with Miriam Coronel-Ferrer, Chair of the Philippines Government Peace Panel, Siem Reap, Cambodia, March 2017. 
Islamist claims and other conflicts more generally when it comes to the likelihood of negotiations, there is one sub-category of Islamist conflicts that clearly stand out in this respect, namely those with transnational linkages. They suggest, building on an argument first developed by Toft and Zhukov (2015), that this is because armed conflicts fought over transnational claims are characterized by both a severely restricted bargaining space in terms of the issues at stake and an unusually high threshold for military costs. The stated political aims in these conflicts are grandiose by nature, striving for a radical challenge to the status quo. The conflict parties often operate across state borders, establishing an extended support network that can sustain the struggle over time even in the face of a temporary national setback. The transcending nature of the conflict also comes with potential reputational costs for governments that may be reluctant to make concessions in the face of potential international repercussions. Taken together, Nilsson and Svensson argue that this explains why transnational Islamist conflicts are less likely to be negotiated.

Several of the other contributions in this issue generally support this argument, albeit with some important nuances with respect to the causal mechanims at work. While a majority of Islamist armed actors publicly claim allegiance to global jihadist networks, such as the Islamic State (ISIS), Al-Qaeda and other Salafi-jihadi armed groups (Melander, Pettersson \& Themnér 2016), the reality on the ground is not so clear, with significant variations when it comes to actual ideological convergence and the extent of external support granted to the armed group by its international allies. For example, Söderberg Kovacs argues that although Boko Haram officially entered into a formal alliance with ISIS in 2016, this cooperation appears to have been primarily symbolic and tactical in kind and the movement remained rooted in a conflict dynamic confined to the Lake Chad sub-region. Sheikh likewise argues that although the Pakistani Taliban movement's linkages to both the Afghani Taliban and Al-Qaeda severely complicated the negotiation process between the armed group and the government, these transnational alliances did not essentially change the outlook of the Pakistani Taliban, who continued to express demands based on local and specific grievances. In both these cases, the transnationalization of the armed non-state group appear to have primarily affected the reluctance of the respective governments in initiating and pursuing negotiations, not the Islamist rebels.

Another compelling explanation with relevance to the question of whom to negotiate with is the emergence of intra-factional rivalry and organizational fragmentation, sometimes as a direct result of external alliances. We know from previous research that the degree of internal cohesion in armed groups 
can affect the prospects for successful conflict resolution (e.g., Cunningham 2011; Pearlman 2009). For this reason, it is important to consider the structure of the organization and on whose behalf a particular faction or leader is engaged in negotiations, and if they have the power and ability to deliver their constituency. According to Sheikh, deep seated divisions and disagreements within the Pakistani Taliban movement have challenged the negotiation processes in several ways and contributed to difficulties in reaching agreements. Like many other Islamist armed movements, the Pakistani Taliban is an umbrella organization consisting of many different factions and warlords. Internal disagreements within the broader movement have primarily concerned differences of opinion with respect to the preferred strategy of the armed struggle or its legitimate representation, although these aspects have at times been entangled with differences over religious interpretations. As a consequence of these internal fallouts, the Taliban leadership has not always been able to unite its fighters or supporters behind negotiated agreements. This, in turn, has raised questions regarding representation at the table, as it has not always been clear who represents the Pakistani Taliban. Spokespersons for the movement at the table have also varied over time, sometimes involving only local commanders, sometimes the central leadership, and sometimes parliamentarians representing the group, but not formally or officially part of the Taliban movement.

Söderberg Kovacs also suggests, based on her case study of the negotiations between the government of Nigeria and Boko Haram, that uncertainty about who was representing the Islamist armed movement at the table was one of the many reasons why the government never put any faith in the peace talks. After the 2009 riots and the massive reprisals by the state that forced the movement underground and into exile, knowledge of the group and its membership remained extremely limited. This was further compounded by the terrorist designation of the movement and the territorial spread of the group throughout the sub-region, which compelled the group to develop a cell-like structure with weak horizontal ties. Partly as a consequence of the sub-regional expansion of the movement and the military counterinsurgency operations, the movement also experienced a gradual factionalization at its leadership level, which contributed to the group's difficulties in agreeing on a joint position. The 2016 split in the movement occurred as a direct result of its allegiance with ISIS, and the intertwined strategic and ideological disagreements that followed in its wake. This tendency toward internal fragmentation may be one of the most important consequences of transnationalization, with key implications for the prospects of negotiation. 


\section{Revisiting Ripeness: When to Negotiate?}

In the conflict resolution literature, the concept of ripeness is well established as a useful analytical lens for understanding when negotiations are more likely to be viewed as a realistic alternative to the parties in conflict (Zartman 1989, 1995). But as discussed in the contributions by both Matesan, and Engvall and Svensson in this issue, we know less about the extent to which ripeness applies to conflicts with Islamist armed groups. A closer examination of the timing of negotiations in Islamist armed conflicts is therefore critical for our quest to better understand the conditions under which such conflicts can be resolved.

According to the basic premises of the theory, there are at least two preconditions that must be in place for warring parties to opt for negotiations over continued warfare. First, they must perceive themselves to be in a situation of a 'mutually hurting stalemate,' where they both believe that the armed struggle has reached a critical impasse or deadlock that they cannot sustain and there are no prospects of achieving military victory within the foreseeable future. Second, both sides must be ready to consider a way out of the conflict, or be ready to act on a 'mutually enticing opportunity' (Zartman 1995, 2001). Both of these conditions are discussed in this issue in the context of Islamist armed conflicts. But first, a few words are needed on the assumed rationality of the actors concerned. Zartman (2000: 239) argues that the concept of ripeness does not apply to "true believers" because they are essentially irrational: not only do they perceive the conflict issue as indivisible and non-negotiable, but they are also less cost-sensitive. While this may be true for some groups, the contributions in this issue show that not all Islamist armed groups are similar in this respect, and there are potentially important variations to consider. Several of the articles also question the notion that the parties' religious motivation or conviction should be considered in isolation, pointing to the complexity of grievances at work. For example, Matesan argues that the concept of ripeness can help us to understand why al-Gama'a al-Islamiyyah (GI) - one of the most ideologically rigid and violent armed groups in Egypt in the 199oswas willing to call for the unconditional cessation of all armed action in 1993. Her analysis suggests that the shift in the rebel group's approach to the usefulness of the armed struggle was driven by an internal organizational crisis and a growing sense of disillusionment with the revolutionary cause, which shaped the group's perception of a hurting stalemate and the need for a way out, suggesting considerations that are both rational and strategic. If we accept that there are variations regarding both the degree to which armed group members 
are convinced ideologues or not, and the degree to which religion is salient in the group's political demands, we should be able to apply the concept of ripeness to Islamist armed groups, although we may need to revisit several more specific conditions.

If we begin with considering the factors that lead to a mutually hurting stalemate, there are a few that stand out in the context of Islamist armed conflicts. We do not yet know if the armed groups in Islamist conflicts are equally vulnerable to military costs and if these dynamics may force them to the negotiation table. One reason is the difficulty of estimating the parties' relative military strength. Much like the situation during the Cold War, most Islamist armed conflicts, even those that are originally grounded in very locally based grievances, tend to become interlinked with the global fight against jihadism, which may affect the available military resources on both the government side and the rebel side. Global jihadist networks - notably those associated with alQueda and Isis - are reaching out to Islamist armed groups across the globe and offer them support in exchange for allegiance. Meanwhile, national governments are offered international military and intelligence support for their counterinsurgency efforts, sometimes in exchange for the adoption of stricter terrorist legislation. Söderberg Kovacs' article on the conflict between Boko Haram and the government of Nigeria, illustrates this development, which inevitable changed both the local conflict dynamics and the difficulty of both parties to perceive of and acknowledge a mutually hurting stalemate. The logical conclusion arising from the comparison with the Cold War is that unless the current global paradigm starts to crumble or the parties successfully delink themselves from this narrative and the ensuing conflict dynamics, the parties to these conflicts may be less likely to perceive a mutually hurting stalemate.

But as noted by Engvall and Svensson in their case study of the Patani conflict, even in situations of a mutually hurting stalemate, ripeness theory dictates that the parties also need to capitalize on this opportunity. This brings us to the second condition, the identification of alternative ways to resolve the conflict that the parties are willing and able to consider as a mutually enticing opportunity. There are several reasons to believe that the possibilities to identify such formulas for a way out are severely constrained in many Islamist armed conflicts. First, the frequent terrorist labeling of Islamist non-state armed groups by national government or inter-governmental organizations such as the United Nations or the European Union, legally and normatively confounds the range of conflict resolution options available for domestic and international peacemakers. It limits both the field of potential mediators and the use of their most common tools, when they are prevented from engaging in diplomatic outreach activities, fact-finding missions, and exploratory talks. 
As illustrated in the case study of Boko Haram in this issue, the terrorist labeling of groups is also likely to lead to the interruption of information flows and increased suspicion between the parties, which further prevents possibilities for rapprochement. This is problematic, as we know that it is only through repeated interaction that confidence is generated between the primary parties, and between the parties and potential mediators. Non-state groups are especially likely to need reassurances to talk to governments.

Both Matesan, and Engvall and Svensson also bring new empirical insights to the debate, with the potential to redefine and develop the concept of ripeness in the context of Islamist armed conflicts. Matesan suggests, based on the case of al-Gama'a al-Islamiyya (GI) in Egypt, that even when the conflict was ripe for negotiation, the ensuing peace talks eventually failed because the public rejected any form of negotiation with and concessions towards the group. Such audience costs, she suggests, is a hitherto unexplored 'dark side' to ripeness. This is a factor that may be especially applicable to the context of Islamist armed conflicts, where the non-state armed actors are often labeled as terrorist organizations. Hence, she argues, ripeness does not only depend on the perception of a mutually hurting stalemate and a way out, but also on public acceptance of concessions. The mental shift from warfare to conflict resolution may be exceptionally challenging in these contexts, pointing to a need to prepare all necessary constituencies for the negotiations. Engvall and Svensson highlight another aspect of ripeness theory that has been largely overlooked in recent scholarly discussions. They suggest that the problem of identifying and engaging so-called 'valid spokespersons' - representative leadership that has the authority to engage in negotiations, is perceived as a legitimate interlocutor, and can convincingly deliver concessions - may be particularly relevant in Islamist armed conflicts. While the notion of valid spokespersons was recognized as the third pre-condition for ripeness in Zartman's early works (1995), this aspect was toned down in later iterations of the theory (Zartman 2001). Engvall and Svensson argue that this is unfortunate, as the findings from their case study of the Patani conflict in southern Thailand suggest that the choice of spokespersons on the rebel side can help to explain why so many peace attempts between the separatist rebels and the Thai government prior to 2013 were aborted by the parties without any concrete results. The reason why the choice of spokesperson matters particularly in this context, they argue, is precisely because of the framing of the armed conflict. While this is a separatist conflict characterized by a multitude of overlapping and constantly shifting identity-markers, the conflict has gradually been framed more explicitly in Islamist rhetoric to mobilize the demands for self-determination for the Malay-Muslim community from the centralized Thai state built on a Buddhist 
identity. In this process, the armed movement has become strongly interlinked with, and dependent on, existing religious authorities in the region. For this reason, a valid spokesperson for the insurgents must anchor its authority in religion to be perceived as valid, both to its own constituency and to its negotiating counterpart. This provides them with legitimacy so that they can exert control over the insurgency and its militants, and be acknowledged by, and have access to, traditional religious authority (see also Drevon 2018).

\section{Re-examining Religion: What to Negotiate?}

A final theme in all the articles in this issue concerns the political goals of the conflict parties, and the implications that religious framing is likely to have for the prospects of negotiation. As noted previously, all of the articles start from a definition of Islamist armed conflicts where at least one of the warring parties express their political aims in religious terms. But as illustrated by the case studies, such religiously framed demands vary significantly from calls for territorial autonomy, partly based on a separate religious identity, to local application of sharia law (Islamic religious law). These differences, as well as complex nuances within the cases across time and space, need to be taken into account to assess what aspects of the conflict issues can and should be open for compromise at the negotiation table. In this section, we discuss some findings related to religion as a conflict issue and the prospects for negotiations.

A first observation is that in none of the case studies was religious incompatibility the focus of political negotiations. But it is not entirely clear how we should interpret this finding. In several of the articles, it is suggested that the bargaining range between the conflict parties is so wide that a political compromise over specific claims are neither possible nor desirable by either side. The 'real demands' are not brought to the negotiation table because neither the Islamists nor their opponents are ready and willing to compromise on matters relating to religious issues. At the same time, there is no empirical evidence to support the notion that resistance to negotiation or failure of the same was solely or even primarily related to the religious conflict issues at stake. In contrast, findings from all the failed cases of negotiations in Egypt, Pakistan, Nigeria and Thailand suggest that the obstacles to negotiation are related to the lack of a perceived mutually hurting stalemate, few realistic and attractive options for a way out, and fragmented conflict parties. If anything, there are reasons to believe that this is why these conflicts are more difficult to resolve: the positive conditions normally associated with negotiations are 
undermined by anti-terrorist legislation, military counterinsurgency operations, and transnational conflict dynamics.

Another important observation is that religious claims were never the only aspect of the armed conflict dynamic. Much like all other armed groups, Islamist armed actors are likely to pursue a range of different objectives, some of which are deemed negotiable and some of which are not. Sheikh discusses these questions in the context of peace talks with various representatives of the Pakistani Taliban. She finds that, in spite of the group's overtly religious political agenda, with the exception of the call for sharia, the religious differences between the parties have not been the primary object of discussion at the negotiation table. Instead, the talks have predominantly concerned local ceasefire arrangements, compensation issues, and other practical and logistical issues regulating the military dynamics between the parties. Söderberg Kovacs finds a similar pattern at work in her study of the negotiations between the government of Nigeria and the group known as Boko Haram. The main demands of the Islamist rebel group at the negotiation table have concerned the release of prisoners, the end of repressive measures by the military and the police, and various forms of justice reforms and compensation for lost lives and property. Even in the absence of formal peace talks addressing the main issues of conflict, negotiations are still possible and have occasionally resulted in short-term ceasefire agreements, although these negotiations have not resolved the main conflict issues.

This brings us to a third finding. As argued by Engvall and Svensson, although there is a non-trivial and indisputable religious component to the conflict issue, it rarely means that the conflict is solely about religion. In their contribution, they discuss the case of the Patani conflict in southern Thailand, where religion has served as an important marker in the conflict, but where there also are other overlapping and constantly changing loyalties linked to ethnicity and regionalism. The same is true for many other so-called state formation conflicts over territorial self-determination, such as, for example, Mindanao in Southern Philippines or Aceh in Indonesia. In these contexts, there are a range of possible bargaining solutions that do not necessarily require a change to the religious claims, something that is discussed by Nilsson and Svensson in their contribution. But the multilayered nature of religiously framed conflicts is equally true for many other conflict contexts, including those fought over government power. For example, as discussed by Söderberg Kovacs, the armed insurrection in the name of Islam in the northeast of Nigeria grew out of a complex mixture of grievances against the federal government based on political marginalization, uneven regional economic development, and state 
repression. Whether religious issues are of high or low salience or play a peripheral or central role in the demands of the parties may depend on a range of historical factors that can have little to do with religion itself (Svensson \& Nilsson 2018). But findings from this issue's contributions also clearly support the notion that the religious framing of the conflict, once formulated, does matter for the prospects of negotiation. As noted by Sheik, armed groups that spend most of the armed conflict claiming that core religious values are at stake make themselves vulnerable to public criticism and loss of legitimacy if they later enter into a negotiation process over exactly those values. This is equally true for both governments and non-state armed groups. Secret diplomatic efforts may therefore provide the best forum for exploring conflict resolution options in these contexts, with greater potential for face-saving maneuvers and pragmatic compromises.

Several articles also raise important questions regarding the specific mechanims for conflict resolution in the context of Islamist armed conflicts. Sheikh explicitly asks whether traditional approaches used in the majority of peace processes over the last three decades - including mechanims such as power sharing, elections, and security sector reform - are equally appropriate in these contexts or if Islamist armed conflicts call for different conflict resolution models. Some political demands that are specific to the context of Islamist armed conflict may require a more elaborate toolbox for peacemakers, especially if they are to be managed within the framework of democratic (and often secular) constitutions and models of governance. Sheikh explicitly discusses the call to adopt sharia, a demand raised not only by some Taliban groups in Pakistan, but by many Islamist armed groups, for example the Moro Islamic Liberation Front (MILF) in the Philippines and the Free Aceh Movement (GAM) in Indonesia. However, the use of sharia may compromise democratic or human rights norms deemed essential by most liberal democratic states and global institutions, not least concerning gender and religious minority rights (Sheikh 2013). This also suggests that religion may not be the originating cause of these conflicts, but it is used as a motivator and mobilizer within the political context. The best way to prevent these conflicts from emerging and escalating might be to provide them with political space and a chance to pursue their goals within a democratic system.

\section{Conclusions}

The rise and emergence of armed conflicts involving Islamist groups in the last decades constitute a grave threat to international peace and security. 
There is a dire need to understand how to resolve such conflicts beyond military means alone. But we have yet to figure out if and how our accumulated scholarly knowledge and our established diplomatic approaches and practical international peace tools are applicable to these conflicts. This includes peace negotiations as a means and method for conflict resolution. All the articles included in this issue start from the notion that this is an open question that needs to be thoroughly examined empirically before we can draw any useful conclusions. They all contribute to addressing various aspects of this overarching problem. In this introductory article, these findings were clustered into three categories: the relevant actors (whom to negotiate with), the timing of such talks (when are negotiations possible), and the content of a negotiated settlement (what issues should be on the negotiation table). In addition to providing valuable input for theory development regarding all these aspects, the articles also suggest areas where more research is needed. This includes, for example, more focus on the role of government in these armed conflicts and the extent to which its narrative, behavior and policies prevent the possibilities for peaceful conflict resolution. The findings also point to some valuable implications for policy and practice when it comes to negotiations with Islamist armed groups. For example, it was suggested that it is possible that Islamist armed conflict requires new and innovative conflict resolution mechanims that are able to integrate Islamist demands with secular constitutions and governance practices. However, more empirical research is needed on this emerging topic before we can arrive at conclusive recommendations.

\section{References}

$B B C$ (2020). "Afghan conflict: US and Taliban sign deal to end 18-year war." February 29. At: https://www.bbc.com/news/world-asia-51689443.

Cunningham, K.G. (2011). "Divide and Conquer or Divide and Concede: How States Respond to Internally Divided Separatists." American Political Science Review 105: 275-297.

Drevon, J. (2018). "Salafi jihadi politication during civil war: Ahrar-al-Sham in Syria." Unpublished conference paper presented at the joint Uppsala University and Folke Bernadotte Academy (FBA) workshop 'Islamist Armed Conflicts and the Prospects for Conflict Resolution, in Schwarzenberg, Switzerland, September 28-30.

Gleditsch, N.P. and I. Rudolfsen (2016). "Are Muslim countries more prone to violence?" Research \& Politics 3, 2: 219-232. 
Melander, E., T. Pettersson and L. Themnér (2016). "Organized violence 1989-2015." Journal of Peace Research 53, 5: 727-742.

Pearlman, W. (2009). "Spoiling Inside and Out: Internal Political Contestation and the Middle East Peace Process." International Security 33, 3: 79-109.

RFI (2020). "Mali open to dialogue with jihadists." February 11. At: http://www.rfi.fr/en/ international/20200211-mali-talk-jihadists-all-inclusive-dialogue.

Svensson, I. (2007). "Fighting with Faith: Religion and Conflict Resolution in Civil Wars." Journal of Conflict Resolution 51, 6: 930-949.

Svensson, I. (2012). Ending Holy Wars: Religion and Conflict Resolution in Civil Wars. Brisbane: University of Queensland Press.

Svensson, I. and E. Harding (2011). "How Holy Wars End: Exploring the Termination Patterns of Conflicts with Religious Dimensions in Asia." Terrorism and Political Violence 23: 133-149.

Svensson, I. and D. Nilsson (2018). "Disputes over the Divine: Introducing the Religion and Armed Conflict (RELAC) Data, 1975-2015." Journal of Conflict Resolution 62, 5: 1127-1148.

Toft, M.D. and Y.M. Zhukov (2015). "Islamists and Nationalists: Rebel Motivation and Counterinsurgency in Russia's North Caucasus." American Political Science Review 109, 2: 222-238.

Zartman, I.W. (1995). "Dynamics and Constraints in Negotiations in Internal Conflicts," in I.W. Zartman, editor, Elusive Peace: Negotiating an End to Civil Wars. Washington, DC: The Brookings Institution.

Zartman, I.W. (2000). "Ripeness: The Hurting Stalemate and Beyond," in P.C. Stern and D. Druckman, (eds.), International Conflict Resolution after the Cold War, Washington, DC: National Research Council.

Zartman, I.W. (2001). "The Timing of Peace Initiatives: Hurting Stalemates and Ripe Moments," Global Review of Ethnopolitics 1, 1: 8-18. 